\title{
Student Vlog for Community Communication Through Social Lab
}

\author{
Pornpapatsorn Princhankol ${ }^{1} \&$ Kuntida Thamwipat ${ }^{2}$ \\ ${ }^{1}$ Faculty of Industrial Education and Technology, King Mongkut's University of Technology Thonburi, Bangkok, \\ Thailand \\ Correspondence: Pornpapatsorn Princhankol, Faculty of Industrial Education and Technology, King Mongkut's \\ University of Technology Thonburi, Bangkok, Thailand
}

Received: September 24, 2020 Accepted: October 30, 2020 Online Published: Nomveber 11, 2020

doi:10.5539/res.v12n4p32

URL: https://doi.org/10.5539/res.v12n4p32

\begin{abstract}
This research was aimed to develop student vlog for community communication through social lab under the ECT Vlog project. In this study, a social lab consists of 3 communities near King Mongkut's University of Technology Thonburi. Other objectives of this study were to determine the quality of the media and activities in this research, to evaluate the perception and the satisfaction of the sampling group towards the student vlog under the ECT Vlog project which was held in the second semester of the academic year 2019. The tools in this study consisted of questionnaires for the quality and the media presentation, the perception assessment form, and the satisfaction questionnaire. The sampling group in this study consisted of 100 followers of the ECT Vlog facebook page who had watched 12 student vlog video clips and were willing to participate in this research. They were chosen using purposive sampling method. The research results have shown that the researchers created 12 Student Vlog video clips for community communication through social lab with 3 communities near King Mongkut's University of Technology Thonburi. The team of creators consisted of the researchers and undergraduate students from the ETM 358 Marketing Communication course. The team analyzed, designed, developed, implemented and evaluated the video clips according to the ADDIE Model which consists of 5 steps. The team analyzed the data, designed the contents and developed 12 student vlog clips and then asked 3 experts in contents and 3 experts in media presentation to evaluate the quality of the video clips. It was found that the quality of contents was at a very good level $) \bar{x}=4.61, S . D=0.38$ ) and that the quality of media presentation was at a very good level $) \bar{x}=4.62$, S.D $=0.43$ ). Afterwards, the researchers distributed the student vlog clips on the ECT Vlog facebook page and assessed the perception of the sampling group. It was found that their perception was at a high level ) $\bar{x}=4.50$, S.D $=0.58$ ). The sampling group expressed a high level of satisfaction towards the student vlog ) $\bar{x}=4.43$, S.D $=0.67$ ), confirming the research hypotheses. It can be concluded that the development of student vlog for community communication through social lab was of good quality and that it could be used in other contexts.
\end{abstract}

Keywords: student vlog, community communication, social lab

\section{Introduction}

Vlog is short for "video blog" and is pronounced "vlog" (one syllable). A vlog is a blog, or web log, that includes video clips. It may be entirely video-based or may include both video and written commentary. Several types of vlogs are available on the Web, including instructional videos, travel updates, and personal commentaries.

People who create vlogs are known as "vloggers." Some vloggers post videos for fun, while others run vlogs for the purpose of generating revenue through advertisements. While it's possible to set up a vlog website, many vloggers post their vlogs on YouTube since it makes their videos easier to find. Additionally, YouTube offers free video hosting, which means vloggers can post unlimited videos without paying web hosting fees (Christensson, P., 2011).

Facebook video has seen a meteoric rise in popularity in the past couple of years; but one of its major advantages is how nicely the videos fit within the site's News Feed. Unlike YouTube, people don't have to go searching for popular videos they usually end up right in front of you. At the moment, YouTube's strength lies in longer videos, like vlogs and "Storytimes" ; but a new blog post from Facebook reveals a change is coming that could completely alter this balance.

Advantages of vlog on facebook are as follows (Liam, D., 2017):

- Facebook use a few different factors to decide how high in your News Feed a video should appear.

- $\quad$ One of these factors is "percentage completed", aka how much of the video you watch before clicking away. 
- Until recently, Facebook's News Feed favoured shorter videos, because those guaranteed a higher percentage completed.

- But now they have announced plans to alter their algorithm, so that longer videos are not punished for not being as completed.

Narongyod M. (2019) summarizes the statistical usage of facebook users in Thailand as follows: There were 45 million accounts for people aged between 18-64 years. 23 million accounts were male and 22 million were female. The majority of accounts were in Central Thailand (12.54 million) followed by accounts in Northeastern Thailand (7.55 million), Northern Thailand (6.92 million) and Southern Thailand (5.01 million). The majority of facebook users graduated from a university. When the users were categorized according to age groups, the biggest group was people aged 18-24 years with 16 million accounts. Other groups were as follows: people aged 25-34 years (15 million), people aged 35-44 years (8.1 million), people aged 45-54 years (4.3 million) and people aged 55-64 years (1.8 million). With the data at hand, the researchers, who were responsible for the ETM 358 Marketing Communication from the Department of Educational Communications and Technology (ECT), Faculty of Industrial Education and Technology, King Mongkut's University of Technology Thonburi, Bangkok, Thailand, decided to conduct this study with the ECT Vlog project on ECT Vlog facebook page for community communication through social lab which was funded by the governmental sector.

During the world's current economic crisis many academic scholars have analyzed Thailand's economy and maintain that capitalism still exists alongside local economy, also known as sufficient economy. In the past, local communities preferred a simple way of life and sufficiency. Every family is a production unit and their kindness works as the basis for their life. They support one another and they work together within their communities. After the governmental introduction of capitalism, the production is unidirectional and consumerism increase the expense of local people. The strength of the local communities is also weakened. After the government and the capital take away the resources from the local communities, the way of life among the local communities is changed. Based on the National Economic and Social Development Plans which have been introduced for over 40 years, only a few communities do not suffer from poverty, environmental problems and health issues. Is it time to convince Thai people to get away from efficiency, value, profit and marketing towards community benefits and society? This is one of the responsibilities of social communicators who need to promote local tourism based on learning so that everybody can collaborate through shared messages of the local communities to the wider society (Sitha P. 2011).

Community-Based Learning or CBL is one way of learning which takes problems as a stimulus to allow learners to use a problem in a community as a way to formulate a hypothesis. This approach will help learners learn how to analyze and solve problems according to the knowledge which they have studied alongside their learning with the community; hence, community-based learning. Students will encounter real problems and learn to think, analyze, create and do other things as part of their thinking exercises. Furthermore, learners will be the center of learning through sub-groups. Instructors will facilitate learners in each sub-group (KMUTT, 2014). In this research, the researchers used this approach in the ETM 358 Marketing Communication course in the second semester of the academic year 2019 under the ECT Vlog project on ECT Vlog facebook page for community communication through social lab in accordance with King Mongkut's University of Technology Thonburi (KMUTT) policy and strategy to develop and evaluate the quality of activities and social lab, namely the learning communities in local areas near the university. They are sites for students, academic scholars and alumni to work with local people in order to share knowledge and develop the community together through academic scholarship and technology so that the communities can gain benefit from this collaboration. In this study, there are 3 communities as follows: Moo 3 Bangmod Community, Langsuan Thonburirom Community, and Community under the Bridge Zone 1. The team for the ECT Vlog project on ECT Vlog facebook page for community communication through social lab would produce 12 video clips to promote local products and address the issues in the community through Student Vlog alongside the researchers in accordance with the 5 steps of the ADDIE Model which involves Analysis, Design, Development, Implementation and Evaluation (Abhicha Anukulwech, 2019). Every step would be under supervision of the experts to maintain the quality and to be revised according to the feedback before being shown to the sampling group.

After the review of research studies regarding social lab during the past 5 years in Faculty of Industrial Education and Technology (Kuntida T., and Pornpapatsorn P. (2020)., Kuntida T., and Pornpapatsorn P. (2019, Kuntida T., Pornpapatsorn P, and Naphat D. (2019,Kuntida T., and Pornpapatsorn P. (2018), Pornpapatsorn P., and Kuntida T. (2018), Kuntida T., Pornpapatsorn P., Sakesun Y., and Sopon M. (2018), Kuntida T., Pornpapatsorn P., and Natchanin K. (2017), Kansombat M., Pornpapatsorn P., and Kuntida T. (2016),Pornpapatsorn P., and Kuntida T. (2015), it was found that there has never been a study into the development of Student Vlog and this study would be about research and development of student vlog for community communication through social lab under the ECT Vlog project. 


\section{Main Parameters of the Study}

\section{Research Objectives}

1. To teach, develop and to determine the quality of student vlog for community communication through social lab under the ECT Vlog project.

2. To evaluate the perception of the sampling group regarding the student vlog for community communication through social lab under the ECT Vlog project.

3. To evaluate the satisfaction of the sampling group towards the student vlog for community communication through social lab under the ECT Vlog project.

\section{Research Hypotheses}

1. The quality of the student vlog for community communication through social lab under the ECT Vlog project would be at a good level or higher than 3.51 on average.

2. The perception of the sampling group regarding the student vlog for community communication through social lab under the ECT Vlog project would be at a high level or higher than 3.51 on average.

3. The satisfaction of the sampling group towards the student vlog for community communication through social lab under the ECT Vlog project would be at a high level or higher than 3.51 on average.

\section{Expected Outcomes}

1. The communication about the community could be achieved through the student vlog for community communication through social lab under the ECT Vlog project.

2. This study would be a way to help increase the channel of the community communication through social lab by Faculty of Industrial Education and Technology, King Mongkut's University of Technology Thonburi for other communities.

\section{Research Scope}

This research and development study was about student vlog for community communication through social lab under the ECT Vlog project which was held in the second semester of the academic year 2019 (January to May 2020). The team for this study consisted of the researchers and undergraduate students who enrolled in the ETM 358 Marketing Communication course. The details are as follows:

Population and Sampling Group

The population in this study consisted of 153 followers of the ECT Vlog facebook page. The sampling group for this study consisted of 100 followers of the ECT Vlog facebook page who had watched 12 student vlog video clips and were willing to participate in this research. They were chosen using purposive sampling method.

Expert Panels

There were 2 expert panels to evaluate the quality. The expert panel for the quality of contents consisted of 3 experts and the expert panel for the quality of media presentation consisted of 3 experts. They would evaluate the quality of the media. They were chosen using specified sampling method out of those who had qualifications and were willing to serve on the panel.

\section{Research Tools}

1. The student vlog for community communication through social lab under the ECT Vlog project

2. The questionnaires to evaluate the quality of the contents and the media presentation of the student vlog for community communication through social lab under the ECT Vlog project

3. The perception assessment form for the sampling group regarding the Student Vlog for community communication through social lab under the ECT Vlog project

4. The satisfaction questionnaire for the sampling group towards the student vlog for community communication through social lab under the ECT Vlog project

\section{Data Analysis}

The statistical methods in this research were mean score and standard deviation. The mean score interpretations are as follows (Boontham K., 2006):

Mean score between 4.51 and 5.00 is interpreted as very good or the highest.

Mean score between 3.51 and 4.50 is interpreted as good or high. 
Mean score between 2.51 and 3.50 is interpreted as

Mean score between 1.51 and 2.50 is interpreted as

Mean score between 1.00 and 1.50 is interpreted as moderate.

low.

the lowest.

\section{Research Results}

The ETM 358 Marketing Communications course for third-year students which we are responsible for has been based on Service Learning and Community-Based Learning approaches for over 7 years. There have also been a number of research studies and the learning achievement tests of the students have been conducted through the After Action Review every time each project was finalized in each social lab around the university campus (within 10 kilometers). This instructional approach is well recognized by local people in the communities. Every project is organized in order to meet the demands of each community through fieldwork, research and media development. There are 5 phases in accordance with the ADDIE Model (Kuntida T., Pornpapatsorn P., Sakesun Y., and Sopon M. (2018).

\begin{tabular}{|c|c|c|}
\hline Phase & Month & Details \\
\hline 1.Analysis & January & $\begin{array}{l}\text { We make a plan and do our fieldwork by interviewing the community for } \\
\text { their needs and activities. }\end{array}$ \\
\hline 2.Design & February & We design media and activities to meet the community demands. \\
\hline 3.Development & March & $\begin{array}{l}\text { We do our fieldwork to develop media and activities to raise the aware of } \\
\text { the project. }\end{array}$ \\
\hline 4.Implementation & March & $\begin{array}{l}\text { We offer the developed media to the community so that they can use them } \\
\text { to promote their community on the Facebook fan page. }\end{array}$ \\
\hline 5.Evaluation & April & $\begin{array}{l}\text { We do another fieldwork by organizing a seminar activity as part of After } \\
\text { Action Review to evaluate the project. }\end{array}$ \\
\hline
\end{tabular}

It can be concluded that there are 9 steps in the development of learners through Service Learning and Community-Based Learning approaches through Social Labs around the university campus as follows:

1) A virtual organization entitled ECT Agency (Educational Communications and Technology - the department name) is established in order to do the following things:

- The whole class of students choose their responsibilities according to their skills on a voluntary basis.

- Students have a meeting and choose their project leader as well as the committee members for each task.

- There will be a weekly meeting. Students from each task will organize it on their own and report their progress to the lecturers.

2) Senior students will talk about what they have learned from working inside a disadvantaged community so that the junior students can find a better way to make things better.

3) The theme for each project must come from the exchange between the educational institute and the community forum along with the data collected through other methods.

4) In classroom, the Service Learning approach involves these 4 stages as follows:

\begin{tabular}{|l|l|}
\hline $\begin{array}{c}\text { Stage } \\
\text { Stage 1 Create }\end{array}$ & $\begin{array}{l}\text { Instructional Method } \\
\text { Create a democratic atmosphere inside the classroom by assigning tasks through } \\
\text { funding by the educational institute and relevant organizations (in accordance with } \\
\text { the good governance policy, the transparency of the administration and the } \\
\text { philosophy of self-sufficiency for administration) }\end{array}$ \\
\hline Stage 2 Stimulate & $\begin{array}{l}\text { Stimulate learners to see the problems or the needs which the community asked } \\
\text { for so that their quality of life can be improved. }\end{array}$ \\
\hline Stage 3 Allow & $\begin{array}{l}\text { Allow or give freedom to students to express their viewpoints and to do every step } \\
\text { of the activity on their own. They can choose or design appropriate } \\
\text { media/activities and the lecturer is merely a coach. }\end{array}$ \\
\hline & $\begin{array}{l}\text { The activities which the learners design or engage with should facilitate them to } \\
\text { apply or to make good use of their knowledge. The lecturer and the students use a } \\
\text { closed facebook group in order that everybody can communicate on an equal } \\
\text { level. }\end{array}$ \\
\hline
\end{tabular}

5) The project is measured, evaluated and presented in a report for the project based on the Principle of Plan-Do-Check-Act.

6) The students submit their summary report to a national contest in order to improve themselves. A group of representative is chosen in order to make a presentation and the whole group support them with data. 
7) The lecturer and the project leader (student) write a research article together and present it in a national and/or international conference so that this will be evidence of lesson learned each year.

8) Everybody works under a win-win situation. In other words, the students learn a lot of things from the community and the community derives benefit from the students.

9) The output from this unique way of operation attracts a lot of attention from the general public, the main channel and the social media channel, resulting in useful information about the project which benefits the community around the university campus each year. This means that there have been many communities benefiting from this kind of instruction for over 7 years.

The developed student vlog for community communication through social lab under the ECT Vlog project contained 12 video clips, some of which are shown her
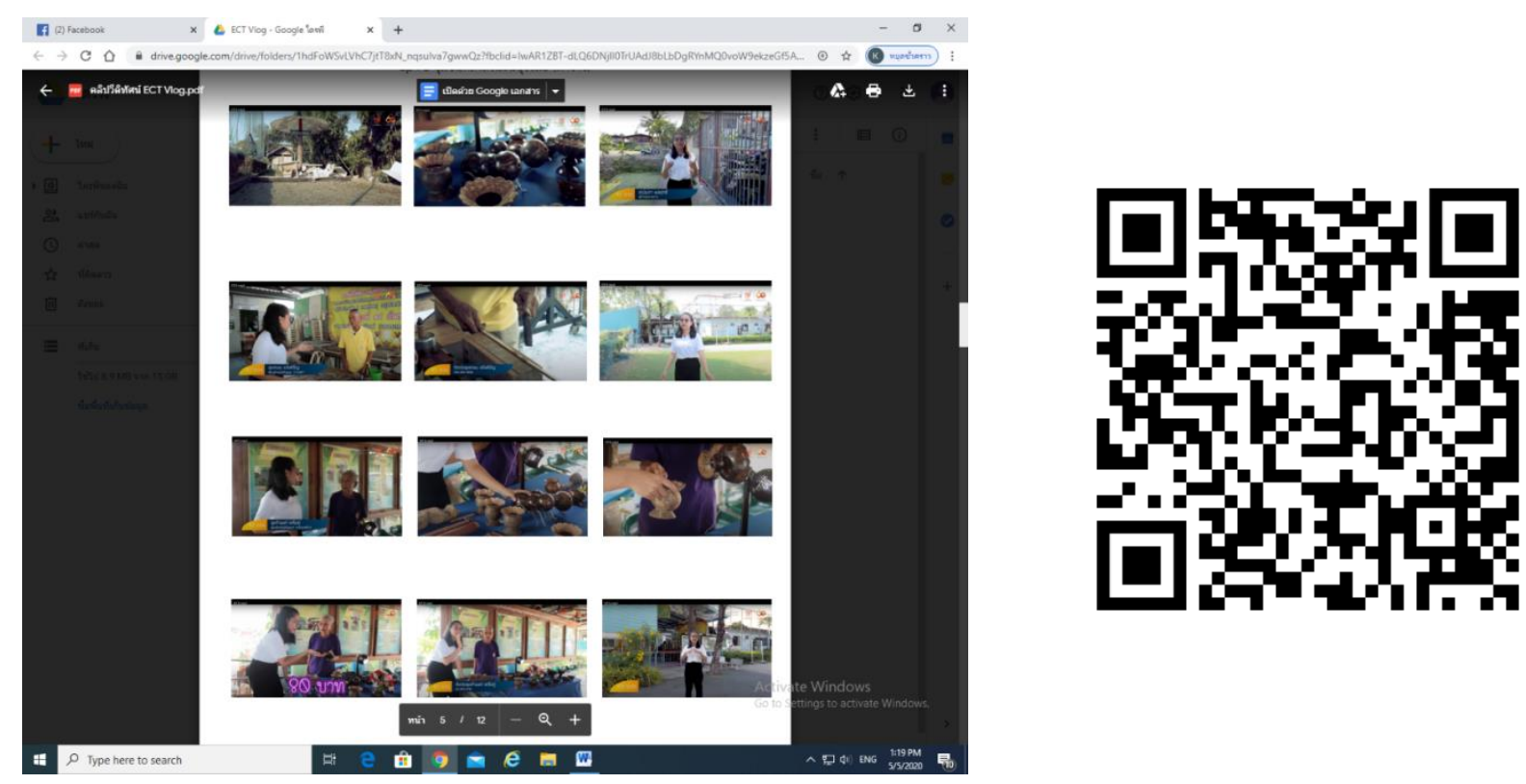

Figure 1. shows a screenshot of student vlog for Langsuan Thonburirom Community: Chula Kite and Coconut Shell
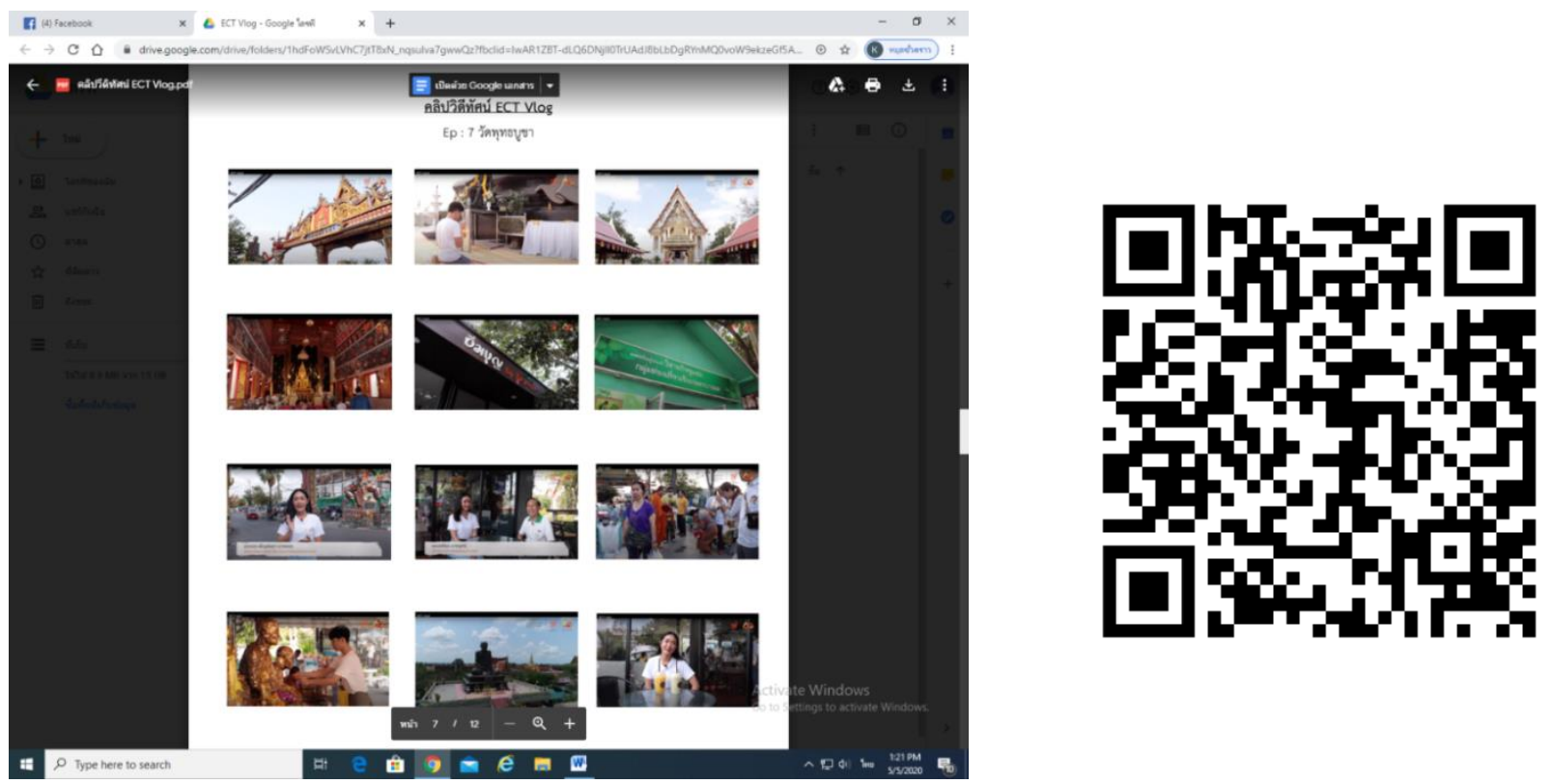

Figure 2. shows a screenshot of student vlog for Moo 3 Bangmod Community: Temple Visit and Local Food 


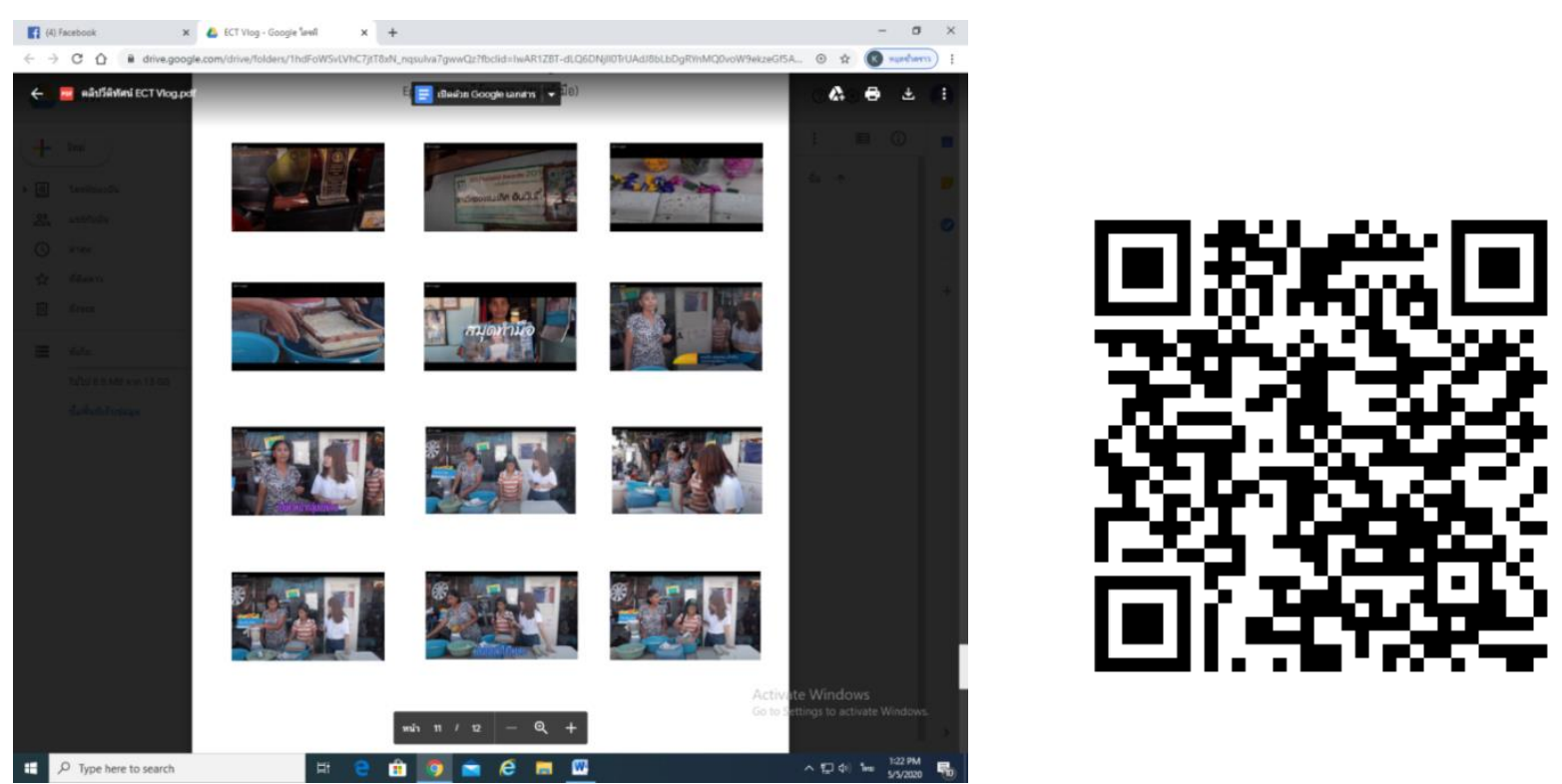

Figure 3. Shows a screenshot of student vlog for Community under the Bridge Zone 1: Handmade Notebook by Housewives the quality of the contents of the Student Vlog as evaluated by the expert panel

The quality of the student vlog as evaluated by the experts in contents is shown Table 1 .

Table 1. Shows the quality of the Student Vlog as evaluated by the experts in contents.

\begin{tabular}{|l|l|l|l|l|}
\hline No & \multicolumn{1}{|c|}{ Item } & Mean & S.D. & \multicolumn{1}{|c|}{ Quality Level } \\
\hline & Contents & & & \\
\hline 1 & The relevance between the contents and the objectives & 5.00 & 0.00 & Very Good \\
\hline 2 & The accuracy of the contents for 3 communities & 5.00 & 0.00 & Very Good \\
\hline 3 & The presentation sequence of the contents for 3 communities & 4.50 & 0.50 & Good \\
\hline 4 & The clarity of the content explanation & 4.50 & 0.50 & Good \\
\hline & Presentation & & & \\
\hline 5 & The suitability of the content presentation & 4.75 & 0.43 & Very Good \\
\hline 6 & The clarity of the presentation & 4.75 & 0.43 & Very Good \\
\hline 7 & The interesting feature of the presentation & 4.50 & 0.50 & Good \\
\hline 8 & The relevance between the contents and the presentation & 4.75 & 0.43 & Very Good \\
\hline 9 & Presentation technique & 4.25 & 0.43 & Good \\
\hline & Language Use & & & \\
\hline 10 & Proper use of language & 4.25 & 0.43 & Good \\
\hline 11 & The suitability of language use to the audience & 4.50 & 0.50 & Good \\
\hline 12 & The clarity of language use & 4.25 & 0.43 & Good \\
\hline 13 & The suitability of language use to the general public & 4.75 & 0.43 & Very Good \\
\hline 14 & The relevance between the language use and the images & 4.75 & 0.43 & Very Good \\
\hline & Total & $\mathbf{4 . 6 1}$ & $\mathbf{0 . 3 8}$ & Very Good \\
\hline
\end{tabular}

According to Table 1, the quality of contents of the student vlog as evaluated by 3 experts in contents was at a very good level $) \bar{x}=4.61$, S.D = 0.38), confirming the research hypothesis. When each item was considered, it was found that the items with the highest mean score were as follows: (a) The relevance between the contents and the objectives with mean score of 5.00 and S.D. of 0.00 and (b) The accuracy of the contents for 3 communities with mean score of 5.00 and S.D. of 0.00 .

The quality of the media presentation of the student vlog as evaluated by the expert panel

The quality of the media presentation of the Student Vlog as evaluated by the experts in media presentation is shown in Table 2 . 
Table 2. Shows the quality of the media presentation of the student vlog as evaluated by the experts in media presentation

\begin{tabular}{|l|l|l|l|l|}
\hline No & \multicolumn{1}{|c|}{ Item } & Mean & S.D. & \multicolumn{1}{c|}{ Quality Level } \\
\hline & Format & & & \\
\hline 1 & Video format & 5.00 & 0.00 & Very Good \\
\hline 2 & Image composition & 4.75 & 0.43 & Very Good \\
\hline 3 & Image sequence & 4.75 & 0.43 & Very Good \\
\hline 4 & Creativity & 4.50 & 0.50 & Good \\
\hline 5 & Content sequence & 4.75 & 0.43 & Very Good \\
\hline & Image & & & \\
\hline 6 & Video recording technique & 4.50 & 0.50 & Good \\
\hline 7 & Video high definition & 4.50 & 0.50 & Good \\
\hline 8 & Video message & 4.50 & 0.50 & Good \\
\hline 9 & Image appropriateness & 4.75 & 0.43 & Very Good \\
\hline 10 & Composition attractiveness & 4.50 & 0.50 & Good \\
\hline & Arts and Actors & & & \\
\hline 11 & Clothing & 4.25 & 0.43 & Good \\
\hline 12 & Make-up & 4.75 & 0.43 & Very Good \\
\hline 13 & Presenters & 4.25 & 0.43 & Good \\
\hline 14 & Interviewees & 5.00 & 0.00 & Very Good \\
\hline 15 & Program Management & 4.50 & 0.50 & Good \\
\hline & Total & $\mathbf{4 . 6 2}$ & $\mathbf{0 . 4 0}$ & Very Good \\
\hline
\end{tabular}

According to Table 2, the quality of media presentation as evaluated by the experts in media presentation was at a very good level $) \bar{x}=4.62, S . D=0.43$ ), confirming the research hypothesis. When each item was considered, it was found that items with the highest mean score were as follows: (a) Video format with mean score of 5.00 and S.D. of 0.00 and (b) Interviewees with mean score of 5.00 and S.D. of 0.00 .

The perception of the sampling group regarding the student vlog

Table 3. Shows the perception of the sampling group

\begin{tabular}{|c|c|c|c|c|}
\hline No. & Item & Mean & S.D. & Perception \\
\hline & $\begin{array}{l}\text { Department of Educational Communications and } \\
\text { Technology }\end{array}$ & & & \\
\hline 1 & $\begin{array}{l}\text { The watcher is aware of details of courses offered by } \\
\text { Department of Educational Communications and } \\
\text { Technology. }\end{array}$ & 4.57 & 0.55 & The Highest \\
\hline 2 & $\begin{array}{l}\text { The watcher knows the teaching methods in courses offered } \\
\text { by Department of Educational Communications and } \\
\text { Technology. }\end{array}$ & 4.51 & 0.57 & The Highest \\
\hline 3 & $\begin{array}{l}\text { The watcher knows about the laboratory of Department of } \\
\text { Educational Communications and Technology. }\end{array}$ & 4.52 & 0.61 & The Highest \\
\hline \multirow[t]{2}{*}{4} & $\begin{array}{l}\text { The watcher knows how to apply for study at Department } \\
\text { of Educational Communications and Technology. }\end{array}$ & 4.60 & 0.57 & The Highest \\
\hline & Bangmod Community & & & \\
\hline 5 & The watcher knows the history of Bangmod Community. & 4.50 & 0.61 & High \\
\hline 6 & $\begin{array}{l}\text { The watcher knows about interesting and cultural sites in } \\
\text { the Bangmod Community. }\end{array}$ & 4.43 & 0.57 & High \\
\hline 7 & $\begin{array}{l}\text { The watcher knows about landmark food shops and cafes in } \\
\text { the Bangmod Community. }\end{array}$ & 4.49 & 0.62 & High \\
\hline \multirow[t]{2}{*}{8} & $\begin{array}{l}\text { The watcher knows the history of orchard in the Bangmod } \\
\text { Community. }\end{array}$ & 4.47 & 0.61 & High \\
\hline & Langsuan Thonburirom Community & & & \\
\hline 9 & $\begin{array}{l}\text { The watcher knows the history of Langsuan Thonburirom } \\
\text { Community. }\end{array}$ & 4.50 & 0.62 & High \\
\hline 10 & $\begin{array}{l}\text { The watcher knows about the local wisdom in the Langsuan } \\
\text { Thonburirom Community. }\end{array}$ & 4.54 & 0.56 & The Highest \\
\hline
\end{tabular}




\begin{tabular}{|l|l|l|l|l|}
\hline 11 & $\begin{array}{l}\text { The watcher knows about activities which are organized by } \\
\text { the Langsuan Thonburirom Community and the university. }\end{array}$ & 4.46 & 0.57 & High \\
\hline 12 & $\begin{array}{l}\text { The watcher knows about prizes which the Langsuan } \\
\text { Thonburirom Community has received. }\end{array}$ & 4.45 & 0.61 & High \\
\hline 13 & Under the Bridge Zone 1 Community & & & \\
\hline 14 & $\begin{array}{l}\text { The watcher knows the history of the Community under the } \\
\text { Bridge Zone } 1 .\end{array}$ & 4.49 & 0.59 & High \\
\hline 15 & $\begin{array}{l}\text { The watcher knows about the way of life of people in the } \\
\text { Community under the Bridge Zone 1. }\end{array}$ & 4.54 & 0.52 & The Highest \\
\hline $\begin{array}{l}\text { The watcher knows about the items which people in the } \\
\text { Community under the Bridge Zone 1 make use of for their } \\
\text { living such as handmade notebooks. }\end{array}$ & $\begin{array}{l}\text { The watcher knows about Dutdao House and the activities } \\
\text { which are organized by the university and the Community } \\
\text { under the Bridge Zone 1. }\end{array}$ & 4.53 & 0.54 & High \\
\hline & \multicolumn{1}{|c|}{ Total } & $\mathbf{4 . 5 0}$ & $\mathbf{0 . 5 8}$ & High \\
\hline
\end{tabular}

According to Table 3, the perception of the sampling group which consisted of 100 followers regarding the Student Vlog was at a high level $) \bar{x}=4.50, \mathrm{~S} . \mathrm{D}=0.58$ ), confirming the research hypothesis. When each item was considered, it was found that the items with the highest mean score were as follows: (a) The watcher knows how to apply for study at Department of Educational Communications and Technology with mean score of 4.60 and S.D. of 0.57; (b) The watcher is aware of details of courses offered by Department of Educational Communications and Technology with mean score of 4.57 and S.D. of 0.55; and (c) The watcher knows about the way of life of people in the Community under the Bridge Zone 1 with mean score of 4.54 and S.D. of 0.52 .

The satisfaction of the sampling group towards the student vlog

The satisfaction of the sampling group towards the student vlog is shown in Table 4.

Table 4. Shows the satisfaction of the sampling group towards the student vlog

\begin{tabular}{|l|l|l|l|l|}
\hline No. & \multicolumn{1}{|c|}{ Item } & \multicolumn{1}{|c|}{ Mean } & S.D. & \multicolumn{1}{c|}{ Satisfaction } \\
\hline & Contents & & & \\
\hline 1 & The relevance between the contents and the objectives & 4.45 & 0.67 & High \\
\hline 2 & The accuracy of the contents for 3 communities & 4.45 & 0.67 & High \\
\hline 3 & $\begin{array}{l}\text { The presentation sequence of the contents for 3 } \\
\text { communities } \\
\text { The clarity of the content explanation }\end{array}$ & 4.35 & 0.70 & High \\
\hline 4 & The suitability of the contents to the audience & 4.37 & 0.70 & High \\
\hline 5 & Format & 4.52 & 0.67 & The Highest \\
\hline & Format & & & \\
\hline 6 & Image composition & 4.43 & 0.72 & High \\
\hline 7 & Image sequence & 4.33 & 0.72 & High \\
\hline 8 & Creativity & 4.37 & 0.72 & High \\
\hline 9 & Content sequence & 4.42 & 0.75 & High \\
\hline 10 & Presentation & 4.40 & 0.68 & High \\
\hline & The suitability of the content presentation & & \\
\hline 11 & The clarity of the presentation & 4.50 & 0.61 & High \\
\hline 12 & The interesting feature of the presentation & 4.50 & 0.59 & High \\
\hline 13 & The relevance between the contents and the presentation & 4.39 & 0.71 & High \\
\hline 14 & Presentation technique & 4.46 & 0.61 & The Highest \\
\hline 15 & Total & $\mathbf{4 . 4 3}$ & $\mathbf{0 . 6 7}$ & High \\
\hline
\end{tabular}

According to Table 4, the sampling group of 100 followers expressed a high level of satisfaction towards the student vlog $\bar{x}=4.43$, S.D = 0.67), confirming the research hypothesis. When each item was considered, it was found that the items with the highest mean score were as follows: (a) The suitability of the contents to the audience with mean score of 4.52 and S.D. of 0.67; (b) The relevance between the contents and the presentation with mean score of 4.51 and S.D. of 0.59; and (c) The suitability of the content presentation with mean score of 4.50 and S.D. of 0.61 .

These are further comments given by the sampling group: 
1) The media was well developed and it was smooth. However, the university logo was not always clear.

2) The program showed creativity and the contents were very good for community communication. However, the male speaker should learn how to improve his articulation.

3 ) The students in the project have developed skills in creating good contents. These video clips will help the communities to communicate with others and should be widely distributed.

\section{Research Discussions}

After the development of the student vlog for community communication through social lab under the ECT Vlog project, there were 12 video clips in accordance with the principle of Plan-Do-Check-Act. The contents were verified by the leaders in each of 3 communities through collaboration. Therefore, the research results confirmed all research hypotheses. There were also 5 phases of this study in relation to the ADDIE Model. This approach is similar to the research by Kuntida T., Pornpapatsorn P., Sakesun Y., and Sopon M. (2018) who made plans, did fieldwork, analyzed the needs, drafted the design and produced media as well as activities alongside assessment activities for each work. The instructional methods also comply with Prasart N. (2015) who suggests that there are 3 steps known as PAR. In the first step, P (Preparation) involves a study of local communities and their needs before deciding on activities and media. In the second step, A (Action) involves learners who need to conduct projects according to the plans. In the third step, R (Reflection) involves each learner in each sub-group to summarize the lessons they have learned through the activities and the reflections by the local communities. The instructors are responsible for the presentation of the comprehensive learning methods in the course so that both learners, communities and educational institutes gain benefit through this collaboration.

The quality of contents of the Student Vlog as evaluated by the experts in contents was at a very good level ) $\bar{x}=$ $4.61, \mathrm{~S} . \mathrm{D}=0.38$ ) and that the quality of media presentation was at a very good level $) \bar{x}=4.62, \mathrm{~S} . \mathrm{D}=0.43$ ), confirming the research hypotheses. This is because the researchers designed the Student Vlog to be in the same harmony with compositions, colors, images, sounds and texts in the same direction and the contents were arranged in an interesting sequence to meet the life style of the target group, in relation to the principle suggested by Margaret Rouse (Margaret Rouse, 2006) in that vlog must be easy to understand. The images must be clear and relevant to the contents. The contents muts be accurate and related to the objectives. Therefore, the quality of the Student Vlog was at a very good level, similar to the research study by Kanyarat W., Kunlanat K., and Supansa N. (2019) who conducted Media Collaborative learning Activities, Vlog Video Media Production for Vocational Students and the quality of their media and activities as evaluated by the expert panels was at very good level for both contents and media presentation) $\bar{x}=4.60, \mathrm{~S} . \mathrm{D}=0.46, \bar{x}=4.62, \mathrm{~S} . \mathrm{D}$ $=0.56)$, respectively.

The perception of the sampling group of 100 followers regarding the student vlog was at a high level) $\bar{x}=4.50$, S.D $=0.58$ ), confirming the research hypothesis. This is because the contents and the format of the media were approved by the expert panels and they were revised many times to be accurate and complete. The undergraduate students in this project did fieldwork in all 3 communities to survey and interview many local people. They filmed their video clips onsite and they interacted with other students to communicate about the community. That is the reason why the perception was at a high level. This is in accordance with theory of perception and selection by Joseph T.K. (1960) who says that there are 4 stages in a selective process from decision to choose, decision to pay attention, decision to perceive and interpret and decision to remember. The production of vlog will be good if we know who the target group is and this will have an impact on the contents and the presentation. The research results of this study are similar to the ones by Kasearin T., Pornpapatsorn P., and Kuntida T. (2019), whose study entitled "the Development of Motion Graphics and Printed Media through QR Code Technology along with Activity to Publicize to tourism of Natural Botany Park under the Initiative of her Royal Highness Princess Maha Chakri Sirindhorn at Suan Phueng District, Ratchaburi Province" shows that their perception was at a high level $) \bar{x}=4.10$, S.D $=0.69$ ). This means that the developed media can be used in actual publicity and it confirms the research hypothesis.

With regards to the student satisfaction, the sampling group of 100 followers expressed a high level of satisfaction towards the Student Vlog $) \bar{x}=4.43$, S.D = 0.67), confirming the research hypothesis. This is because the Student Vlog was developed according to good practices in vlog production. Wipa A.(2001) says that good contents will gain attention from the audience and that good editing will make the story flow. With eye-catching perspectives and interesting contents and uploaded files for the audience to find for themselves, the media will be effective. This is similar to the research study by Kansombat M., Pornpapatsorn P., and Kuntida T. (2016) whose study entitled "The Development of Learning Resources "Chula Kite Local Wisdom" of Suan Thonburirom Community through Social Service Learning Approach by Students from Faculty of Industrial Education and Technology, KMUTT" shows that their sampling group expressed a high level of satisfaction because the study was a kind of community-based learning. The students in that course also expressed a high level of satisfaction. The instructors used this approach to allow learners to increase their responsibility to their society in accordance with the 5 steps proposed by Tissana Khamanee (2007) as follows: 1) teaching learners to analyze the 
demands of the community before media production; 2) planning; 3) operating according to the plan; 4) reflecting on their action; and 5) shared conclusion through the use of bodies of knowledge for community communication.

\section{Suggestions}

\subsection{Suggestions From the Research Results}

1. The development of the student vlog for community communication through social lab under the ECT Vlog project has shown that it could be used in actual contexts. Therefore, this approach can be used in other courses which require presentation skills and extracurricular activities to promote marketing communication. Vlog can be used in other courses to publicize departments in universities and communities because it is interesting and easy to follow.

2. The research results have shown that the perception of the audience was at a high level because the contents and the format were approved by the expert panels and they were revised many times during the planning stage. The undergraduate students also did fieldwork in all 3 communities by asking for opinions and surveys and the students learned from one another through communication. Therefore, every party has gained a higher level of perception regarding the communities.

3. It was found that the principle of Plan-Do-Check-Act is very important because the team members could work carefully and check their error before and during the operation. Moreover, it is important to know the target group so that the contents, the format and the topics can be set up to meet the demands.

4. The production of vlogs by competent vloggers who can communicate about communities will be a good approach to community-based learning or communication for social development in other courses.

\subsection{Suggestions for Further Research}

1. There should be a study and development of student vlog for community communication through social lab about other departments in the university, or achievements of the university or other communities in the future.

2. There should be a study into the factor analysis of media and activities to promote active learning through in-depth interviews between learners and community members.

\section{Acknowledgements}

The researchers would like to thank Department of Educational Communications and Technology, Faculty of Industrial Education and Technology, King Mongkut's University of Technology Thonburi for funding this study and we would like to extend our gratitude towards the leaders in 3 communities near the university for their support and collaboration in this project.

\section{References}

Abhicha, A. (2019) .ADDIE MODEL. Retrieved 2020, Apr 14, from: http://lms.thaicyberu.go.th/

Boontham, K. (2006). Technique in Creating Tools for Research Data Collection. $3^{\text {rd }}$ Imprint. Chamchuri Product, Bangkok, pp. 45-46.

Christensson, P. (2011). Vlog Definition. Retrieved 2020, Apr 14, from https://techterms.com

Joseph, T. K. (1960). The Effect of Mass Communication. New York: The Free Press, pp.19-23.

Kansombat M., Pornpapatsorn P., \& Kuntida, T. (2016). The Development of Learning Resources "Chula Kite Local Wisdom" of Suan Thonburirom Community through Social Service Learning Approach by Students from Faculty of Industrial Education and Technology,KMUTT. The 42 nd Congress on Science and Technology (STT42). Centara Grand at Central Ladprao Bangkok, Thailand. November 30-December 2, 2016.pp.879-888.

Kansombat, M., Pornpapatsorn, P., \& Kuntida, T. (2016). "The Development of Learning Resources "Chula Kite Local Wisdom" of Suan Thonburirom Community through Social Service Learning Approach by Students from Faculty of Industrial Education and Technology, KMUTT"'. The 42 nd Congress on Science and Technology (STT42). Centara Grand at Central Ladprao Bangkok, Thailand. November 30-December 2. pp. 879-888.

Kanyarat, W., Kulanat, K., \& Supansa, N. ( 2019 ). "Media Collaborative learning Activities, Vlog Video Media Production for Vocational Students". Bacherlor Research Project of Educational Technology and Mass communication. Industrial Education Technology King Mongkut's University of Technology Thonburi. pp. 4.

Kasearin, T., Pornpapatsorn, P., \& Kuntida, T. (2019). "The Development of Motion Graphics and Printed Media through QR Code Technology along with Activity to Publicize to tourism of Natural Botany Park under the Intiative of her Royal Highness Princess Maha Chakri Sirindhorn at Suan Phueng District, Ratchaburi Province "NCTechED The 6 th International NCT11. March 25-26, 2019.pp. 15-19. 
King Mongkut's University of Technology Thonburi. (2014). Report on University and Community. Retrieved 2020, Apr 14, from :www2.kmutt.ac.th/thai/info_report.pdf

Kuntida, T., \& Pornpapatsorn, P. (2020). Findings from the Development Communication through the Social Lab Project Entitled "ECT imparts knowledge to local communities. Review of European Studies, 12(1), 55-65. https://doi.org/10.5539/res.v12n1p55

Liam, D. (2017, July 17). Vlogging Might Become A 'Thing' On Facebook Video And Here's Why. Retrieved 2020, Apr 14, from https://www.wetheunicorns.com/news/longer-vlogging-facebook-video/

Margaret, R. (2006). VLOG (Video Blog ). Retrieved 2020, May 14, http:// whatis.techtarget.com/definition/Vlog-video - blog

Narongyod, M. (2019). Facebook in Thailand. Retrieved 2020, Apr 14, from https://www.twfdigital.com/blog/2019/10/facebook-demography-thailand-q4-2019/

Pornpapatsorn, P., \& Kuntida, T. (2015). "The Development of Media and Activities to Promote Learning for Children in Disadvantaged Communities: A Case Study of Creative Media @ Community under the Bridge Zone 1 Regarding Sex Education".the 4 th World Conference-EDUCON 2015 at KHALSA College of Education. November 27-28, 2015, Amritsar, India, pp. 44.

Prasart, N. (2015). Service Learning. Praewa Kalasin Journal of Kalasin Rajabhat University. Vol. 2, No. 1, January April 2015, pp. 14-15.

Princhankol, P., \& Thamwipat, K. (2018). The Development of Media and Special Event through Cooperative Learning to Raise Funds for Students with Financial Difficulties at Faculty of Industrial Education and Technology. International Education Studies, 11(11), 88-94. https://doi.org/10.5539/ies.v11n11p88

Sitha, P. (2011). Wealthy Local Village: Healthy Planet: Happy Documentary about Cultural Tourism for Learning. Retrieved 2020, Apr 14, from http://resource.thaihealth.or.th/library/collection/14183

Thamwipat, K., \& Princhankol, P. (2018). The Development of Media and Special Event to Support Knowledge of Arts and Culture Entitled" Dancing with Single-Head Drum Accompaniment" for Young People through Social Service Learning and Community-Based Learning. International Education Studies, 11(12), 133-139. https://doi.org/10.5539/ies.v11n12p133

Thamwipat, K., \& Princhankol, P. (2019). The Development of Innovative Multimedia through Social Lab to Promote Perception of Good Citizenship according to Democratic Values. Rev. Eur. Stud., 11, 21. https://doi.org/10.5539/res.v11n4p21

Thamwipat, K., Pornpapatsorn, P., \& Kaewket, K. (2017). Developing a Lesson Based on the 'Service-Learning'Principle through the Project to Create a Community Calendar to Promote 12 Values. In $3 r d$ International Conference on Education and Distance Learning.

Thamwipat, K., Princhankol, P., \& Deeyen, N. (2019). The Development of Multimedia and Activities to Promote Products Made by State Enterprise Communities in the Bangmod Project 4.0 through Community-Based Learning. International Education Studies, 12(4), 49-59. https://doi.org/10.5539/ies.v12n4p49

Thamwipat, K., Princhankol, P., Yampinij, S., \& Meejaleurn, S. (2018). The Development of Media Activities by Undergraduate Students in Order to Promote Agricultural Tourism Community Enterprise According to the Principles of Social Service Learning and Community-Based Leaning. International Education Studies, 11(5), 38-45. https://doi.org/10.5539/ies.v11n5p38

Tissana, K. (2007). The Development of Ethics, Morality and Values: From Theory to Practice: Nontaburi: Songsermwichakarn Center

Wipa, A. (2001). Production of TV Media and Computer Media: Creative Process and Production Technique. $2^{\text {nd }}$ Imprint. Bangkok: SE-ED, pp. 85-86.

\section{Copyrights}

Copyright for this article is retained by the author(s), with first publication rights granted to the journal.

This is an open-access article distributed under the terms and conditions of the Creative Commons Attribution license (http://creativecommons.org/licenses/by/4.0/). 